\title{
Mediating Role of Job Satisfaction on Internal Corporate Social Responsibility Practices and Employee Engagement in Higher Education Sector
}

\author{
Md. Monir Hossen \\ Faculty of Business, Social Sciences and Hospitality Management, SEGi University, \\ Malaysia \\ E-Mail: monir.hossen301@gmail.com \\ Tak-Jie Chan \\ Faculty of Business, Social Sciences and Hospitality Management, SEGi University, \\ Malaysia \\ E-Mail: chantakjie@ segi.edu.my \\ Nurul Ain Mohd Hasan \\ Faculty of Modern Languages and Communication, Universiti Putra Malaysia, \\ Malaysia \\ E-Mail: namh@upm.edu.my
}

\begin{abstract}
The study aims to investigate the relationship between internal corporate social responsibility (ICSR) practices and employee engagement through job satisfaction as a mediating variable. The ICSR dimensions are comprised of employee empowerment, education and training, employment stability, as well as a working environment. This study is based on the social exchange theory to explore the relationship between the above factors and ICSR. In this study, purposive sampling was adopted. A quantitative (survey) method was employed, generating 93 valid responses. The data was then analyzed using Partial Least Square Structural Equation Modelling through Smart-PLS 3.0. The results revealed that ICSR practices, namely employee empowerment, and employment stability contributed positively to job satisfaction. However, training \& education and working environment were found not significant to job satisfaction. In addition, job satisfaction has a positive influence on employee engagement. The results of the study found that except for training, education, and the work environment, job satisfaction mediates the relationship between ICSR practices and employee
\end{abstract}


engagement. Conclusion, implications of the findings, and suggestions for future study are also discussed.

Keywords: Employee engagement, Higher education institution, Internal corporate social responsibility, Job satisfaction

\section{INTRODUCTION}

Internal corporate social responsibilities (ICSR) is increasingly trending in organizational studies. Studies surrounding ICSR remain crucial that often aim to understand the success of an organization and help attract and retain employees (Obrad \& Gherheş, 2018). Organizations are looking for ways to build stronger engagement with their employees because satisfied and committed employees are the asset that drives the triumph of the organizations (Bakotić, 2016; Bayraktar \& Şencan, 2017). For instance, a report done by the World Bank Group (2019) showed that Malaysia is becoming a place for talented employees; however, due to the lack of human capital development, a large portion of Malaysians still lack the skills required for a successful career path. As a result, the country is ranked 55 out of 157 in terms of skills and professional labor force (Aturupane \& Richard, 2019).

In developing countries, the practice of ICSR is an increasingly prominent topic for research within the scope of the business, public relations, and organizational communication (Chan \& Mohd Hasan, 2018; Gharleghi, Jahanshahi, \& Nawaser, 2018). In addition, making a knowledge-based economy and getting a competitive advantage to require a set of workforce who are talented and committed. As highlighted by Gao (2019), practicing ICSR can help strengthen employee engagement. Thus, taking into consideration the factors of ICSR in organizational practices will provide enriching insights into achieving the goals of the industry.

Ranjan and Yadav (2018) found that the turnover rate in the education industry is higher compared to other industries. The notion further supports Ramasamy and Abdullah (2017), where employee disengagement in the universities may result in loss of progress for the institutions. The issue has been frequently highlighted in the mass media and government official reports; however, empirical research on ICSR studies which focuses on higher education institution (HEI) is still sacred in the Malaysian setting (Ghasemy et al., 2018; Low, 2020; Sani \& Mustafa, 2019).

Moreover, it is found that not many studies have used job satisfaction as a mediating variable between ICSR and employee engagement in higher education research (Khan, Yusoff, Hussain, \& Ismail, 2019). Therefore, this study aims to apply job satisfaction as a mediating variable between ICSR practices and employee' engagement by applying it in a private HEI in Malaysia. 
The findings of the previous studies were inconsistent. For instance, Obeidat, Altheeb, and Masa'deh (2018) found that skills development and employment stability are not significantly related to job satisfaction; however, the findings from Khan et al. (2019) found that those variables have a significant relationship with job satisfaction. A study by Low and Ong (2015) stated that job satisfaction is not significantly related to employee turnover and employee engagement. In contrast, Singh, Sethuraman, and Lam (2017) found that they are significantly related to each other. Esmaeelinezhad, Singaravelloo, and Boerhannoeddin (2015) revealed that ICSR practices are not significantly related to job satisfaction and employee engagement; however, the study of Farid et al. (2019) indicated that those variables are actually significantly related. The inconsistency of past studies suggests that more research is needed and that various factors may influence the inconsistencies, such as the environmental and cultural setting of a given nation.

From a theoretical perspective, social exchange theory (SET) is considered appropriate to this study as it explains the reciprocal relationship between ICSR practices, job satisfaction, and employee engagement (Slack, Corlett, \& Morris, 2015; Zulfiqar, Sadaf, Popp, Vveinhardt \& Máté, 2019). In other words, the ICSR practices are the basis of exchange, which the HEIs use to gauge the positive social exchange interactions. Based on the voids highlighted above, therefore, the current study aims to test the mediating role of job satisfaction on the relationship between ICSR practices (employee empowerment, training \& education, employment stability, working environment) and employee engagement.

\section{LITERATURE REVIEW}

\section{Definitions of Internal Corporate Social Responsibility}

ICSR includes policies and guidelines that can improve the physical environment, such as a workplace that is free from health and safety issues for maximum engagement (Hernández-Murillo \& Martinek, 2009). Some initiatives of ICSR range from empowerment, such as evaluating their decisions and priorities, to securing their worklife balance, such as flexibility and vacation (Cavazotte \& Chang, 2016). Therefore, the Malaysian government included a few important elements in their ICSR practices for employees, such as workplace environment, employees, and governance (Lim, Ramakrishnan \& Hishan, 2018). Ranjan and Yadav (2018) mentioned that, since the practice of ICSR is for employees, hence, it would be advisable to focus on the benefits that the employees are looking for, such as facilitating skills and professional development, workplace diversity, and a good working environment. This will motivate the employees to increase their engagement and commitment. 


\section{Relationship Between ICSR, Job Satisfaction and Employee Engagement}

Several past studies found that there is a significant and positive relationship between ICSR practices and employee job satisfaction based on various industries (Obeidat et al., 2018; Low, Ong, \& Tan, 2017). For example, a study of fourteen Jordanian pharmaceutical companies showed that by practicing ICSR will increase the effectiveness and productivity of employees. In return, they were able to strengthen their positions in the market (Obeidat et al., 2018).

Esmaeelinezhad et al. (2015) conducted a study on Iranian four corporate companies and found that ICSR and job satisfaction have positive effects on an organization that can minimize the turnover rate among employees. Based on the discussion, these advocate that job satisfaction can lead to competitive advantages, such as low turnover, productivity, and client appraisal. An investigation by Idris, See, and Coughlan (2018) investigated the relationship between employee empowerment and job satisfaction in a social-cultural and organizational environment. They concluded that in the Malaysian context, employee empowerment has a significant connection with job satisfaction. At the same time, job satisfaction varies depending on the status or position of the employees.

The discussion above is aligned with Crede, Chernyshenko, Stark, Dalal, and Bashshur's (2007) notion that the factors of ICSR influence employees' job satisfaction and job satisfaction, it will motivate employee engagement. Finally, it helps to extend the understanding in regard to the exchange relationship in organizations, which is supported by the social exchange theory (Blau, 1964).

In addition, Manimegalai and Baral (2018) conducted a study on 486 Malaysian hotel employees, and the findings showed that job satisfaction partially mediates the relationship between ICSR practices and employee engagement. Another study by Fu, Ye, and Law (2014) found that ICSR practices influence employee engagement through the mediating effects of job satisfaction. Similarly, Lee and Kim (2013) conducted a study on 306 employees and explained the underlying mechanism linking the dimensions of ICSR practices by organizations and employee engagement. Based on the above notion it revealed that job satisfaction has a mediating relationship between ICSR practices and employee engagement.

Based on the above-mentioned studies it shows that job satisfaction can be the underlying mechanism to connect ICSR practices and employee engagement. Hansen, Dunford, Boss, Boss, and Angermeier (2011) argued that in terms of employee turnover, trust partially mediates the connection between ICSR and engagement. Therefore, this study predicts that in the higher education sector, job satisfaction as another potential variable that can affect the relationship between ICSR practices and employee engagement, which makes researchers include job satisfaction as the 
mediating variable in this study. In addition, the findings of the previous studies positively supported the relationship between ICSR practices and job satisfaction (Barakat, Isabella, Boaventura, \& Mazzon, 2016; Chan \& Mohd Hasan, 2019) and job satisfaction and employee engagement (Tepayakul \& Rinthaisong, 2018). Based on these discussions, this study argues that the positive organizational activities related to the ICSR practices will increase job satisfaction among the employees, which subsequently has an impact on employee engagement.

Based on the foregoing discussion, therefore, this study hypothesizes that:

$\mathrm{H}_{1}$ : There is a positive relationship between employee empowerment and job satisfaction.

$\mathrm{H}_{2}$ : There is a positive relationship between training \& education and job satisfaction.

$\mathrm{H}_{3}$ : There is a positive relationship between employment stability and job satisfaction.

$\mathrm{H}_{4}$ : There is a positive relationship between the working environment and job satisfaction.

$\mathrm{H}_{5}$ : There is a positive relationship between job satisfaction and employee engagement.

$\mathrm{H}_{6}$ : Job satisfaction mediates the relationship between internal CSR practices (employee empowerment, education \& training, employee stability, working environment) and employee engagement.

\section{METHODOLOGY}

\section{Research Design}

This study utilized a quantitative (survey) design to solicit responses from the employees of the private HEI. The survey method was selected because it was more cost-effective and time-efficient to gather large responses from the identified population (de Leeuw, 2008). According to Babbie (2015), survey design is a suitable method to apply in this study as it allows the researchers to measure the attitudes and opinions of respondents.

\section{Population and Sampling}

The sampling technique used in this study was non-probability sampling (purposive sampling) as researchers were unable to solicit a detailed list of the population due to confidentiality issues. Hence, this limitation did not allow researchers to utilize probability sampling. The concept of purposive sampling is the focus on subjects who possess a particular characteristic in the research (Etikan, Musa, \& Alkassim, 2016; Tongco, 2007). Since ICSR is normally a top-down strategy or planning, hence, not all employees will have the knowledge or are aware of it. Hence, this study selects the academic staff and administrative staff with at least a degree 
qualification. Operational employees were not included in this study. For the data collection, a structured anonymous questionnaire was distributed to the employees and generated 93 valid responses. This further supports the notion by Sekaran and Bougie (2016) that a sample size ranging from 30 to 500 is sufficient and acceptable for social science studies. In addition, Hair, Hult, Tomas, Ringle, and Sarstedt (2017) claimed that in PLS-SEM, the number of respondents below 100 could also provide significant results.

\section{Instrument/ Measurement}

This study is comprised of three sections. Section A was about the demographic profile of the respondents such as gender, staff, nationality, race, level of education, and tenure. Section B regards the dimension of ICSR practices, where the items for training and education were adapted from (Al-bdour, Ali, Nasruddin, \& Soh, 2010; Lee \& Bruvold, 2003), employees empowerment, employees stability, and working environment were adapted from Mory et al. (2015). Section C measures of job satisfaction in which items were adapted from Macdonald and Maclntyre (1997). Section D measures employee engagement, and items for this section were adapted from Al-bdour et al. (2010).

In this study, 5 points Likert-type scale is used for all the latent variables, where one represents strongly disagree, two indicates Disagree, three represents Slightly Agree, four indicates Agree, and five represents Strongly Agree. Respondents were given the freedom to express their views on the series of items about the ICSR practices of the university.

\section{Statistical Analysis and Significance}

The main purpose of the study is to examine the relationship or the influence of ICSR on employee job satisfaction and engagement. Hence, structural equation modeling (SEM) is deemed a suitable statistical tool for this study as PLS-SEM is able to handle complex models for a larger amount of latent variables and constructs (Henseler, Ringle, \& Sinkovics, 2009). In this research it has six variables with 38 indicators, which can be considered a complex model. In addition, PLS-SEM can handle small and non-normal distribution data as well (Awang, Afthanorhan, Asri, 2015; Hair, Risher, Sarstedt, \& Ringle, 2019).

\section{RESULTS}

More than half of the respondents are female employees (61.3\%). Out of 93 respondents, the majority are Malaysians, which contributed to $88.2 \%$, and the remaining $11.8 \%$ are Non-Malaysian. More than half of the respondents have their 
bachelor's degrees $(55.9 \%)$, while only $8.6 \%$ of the respondents are Ph.D. holders. In terms of tenure, $28.0 \%$ of employees working for the institution for 2-3 years; comparatively, among different tenure duration, the employees who have 6-7 working years are the lowest $(12.9 \%)$.

Before testing the model, this study examined the common method variance (CMV), which is the method bias or same source bias that may arise using self-report measures from a similar sample in survey methods (Podsakoff, MacKenzie, Lee, \& Podsakoff, 2003). In this study, the correlation matrix procedure was used as one of the methods to detect CMV (Bagozzi, Yi, \& Phillips, 1991; Tehseen, Ramayah, \& Sajilan, 2017). CMV occurs when there is a substantially high correlation found among latent variables $(r>0.9)$. The outcome of the correlation test indicated that none of the latent variables correlated more than 0.90 . Hence, the result assured that CMV was not an issue in this study.

Table 1 Correlation Matrix among the Latent Variables

\begin{tabular}{lcccccc}
\hline & TE & ES & EP & WE & EE & JS \\
\hline TE & 1 & & & & & \\
ES & $.625^{* *}$ & 1 & & & & \\
$\mathbf{E P}$ & $.647^{* *}$ & $.806^{* *}$ & 1 & & & \\
$\mathbf{W E}$ & $.499^{* *}$ & $.696^{* *}$ & $.687^{* *}$ & 1 & & \\
$\mathbf{E E}$ & $.635^{* *}$ & $.845^{* *}$ & $.745^{* *}$ & $.644^{* *}$ & 1 & \\
$\mathbf{J S}$ & $.679^{* *}$ & $.846^{* *}$ & $.803^{* *}$ & $.692^{* *}$ & $.885^{* *}$ & 1 \\
\hline
\end{tabular}

Note. ${ }^{* *}$ Correlation is significant at the 0.01 level (1-tailed).

All the hypotheses developed were examined using SEM. Two-stage analytical procedures were performed using Smart-PLS 3.0. The measurement model was first tested and followed by the structural model.

\section{Measurement Model}

Two types of validity, namely convergent validity and discriminant validity, were assessed in the measurement model. The convergent validity of the measurement model was ascertained by examining factor loadings, average variance extracted (AVE), and composite reliability (CR) (Hair et al., 2017).

As shown in Table 2, the factor loadings were all greater than 0.7 , which was supported by Hair, Ringle, and Sarsterd (2011). Three items, TE2, WE6, and JS2, with factors loading less than 0.5, were deleted. The AVE and CR obtained were all higher than 0.5 and 0.7 , respectively, as suggested by Hair et al. (2017). 
Table 2 Reflective Measurement Model: Factor Loading, Alpha, CR, and AVE

\begin{tabular}{|c|c|c|c|c|c|c|}
\hline Construct & Item & $\begin{array}{c}\text { Item } \\
\text { Deleted }\end{array}$ & Loadings & Alpha & $\mathbf{C R}$ & AVE \\
\hline \multirow[t]{7}{*}{ Training \& Education (TE) } & TE1 & TE2 & 0.835 & 0.919 & 0.935 & 0.673 \\
\hline & TE3 & & 0.761 & & & \\
\hline & TE4 & & 0.843 & & & \\
\hline & TE5 & & 0.864 & & & \\
\hline & TE6 & & 0.825 & & & \\
\hline & TE7 & & 0.822 & & & \\
\hline & TE8 & & 0.788 & & & \\
\hline \multicolumn{7}{|l|}{ Employee Empowerment (EP) } \\
\hline & EP1 & & 0.878 & 0.922 & 0.941 & 0.762 \\
\hline & EP2 & & 0.820 & & & \\
\hline & EP3 & & 0.865 & & & \\
\hline & EP4 & & 0.893 & & & \\
\hline \multirow[t]{5}{*}{ Employment Stability (ES) } & EP5 & & 0.906 & & & \\
\hline & ES1 & & 0.907 & 0.926 & 0.945 & 0.773 \\
\hline & ES2 & & 0.876 & & & \\
\hline & ES3 & & 0.900 & & & \\
\hline & ES4 & & 0.820 & & & \\
\hline \multirow[t]{4}{*}{ Working Environment (WE) } & ES5 & & 0.890 & & & \\
\hline & WE1 & WE6 & 0.855 & 0.936 & 0.951 & 0.796 \\
\hline & WE2 & & 0.918 & & & \\
\hline & WE3 & & 0.920 & & & \\
\hline \multirow[t]{7}{*}{ Job Satisfaction (JS) } & WE4 & & 0.896 & & & \\
\hline & WE5 & & 0.871 & & & \\
\hline & JS1 & JS2 & 0.849 & 0.950 & 0.959 & 0.768 \\
\hline & JS3 & & 0.916 & & & \\
\hline & JS4 & & 0.900 & & & \\
\hline & JS5 & & 0.834 & & & \\
\hline & JS6 & & 0.880 & & & \\
\hline \multirow[t]{6}{*}{ Employee Engagement (EE) } & JS7 & & 0.868 & & & \\
\hline & JS8 & & 0.886 & & & \\
\hline & EE1 & & 0.896 & 0.922 & 0.945 & 0.811 \\
\hline & EE2 & & 0.900 & & & \\
\hline & EE3 & & 0.903 & & & \\
\hline & EE4 & & 0.903 & & & \\
\hline
\end{tabular}

Note. $\mathrm{AVE}=$ Average Variance Extracted and $\mathrm{CR}=$ Composite Reliability.

Two criteria, Fornell-Larcker (1981) and Heterotrait-Monotrait (HTMT) (Henseler, Ringle, \& Sarstedt, 2015) were used to assess discriminant validity. The Fornell-Larcker (1981) criterion was examined by comparing the square root of the AVE with the correlations between the constructs. Table 3 shows that all the square 
roots of AVE (diagonal values) are more than the correlation coefficient between the constructs (off-diagonal values), indicating that discriminant validity is adequate (Fornell-Larcker, 1981). Discriminant validity is established if all the HTMT values obtained are less than the required threshold of HTMT.85 (Kline, 2011) or HTMT.90 (Gold, Malhotra \& Segars, 2001). As shown in Table 4, three comparison points have slightly more than 0.90; however, this study utilized the HTMTinference as suggested by Henseler et al. (2015), which argued that the HTMT values not more than one on any of the constructs indicated that there is no discriminant validity issue. This is further supported by Ramayah, Cheah, Chuah, Ting, and Memon (2018) that the HTMT should be significantly lower than one (liberal criterion). Therefore, discriminant validity was ascertained. The collinearity issue was assessed using the variance inflation factor (VIF) with a cut-off value of 5, as suggested by Hair et al. (2017). The VIF values, as presented in Table 5, were all less than 5, indicating no collinearity problems.

Table 3 Fornell \& Larcker Criterion Values

\begin{tabular}{lcccccc}
\hline & EP & JS & TE & EE & ES & WE \\
\hline Empowerment (EP) & $\mathbf{0 . 8 7 3}$ & & & & & \\
Job satisfaction (JS) & 0.809 & $\mathbf{0 . 8 7 6}$ & & & & \\
Training education (TE) & 0.627 & 0.629 & $\mathbf{0 . 8 2 0}$ & & & \\
Employee engagement (EE) & 0.751 & 0.895 & 0.613 & $\mathbf{0 . 9 0 0}$ & & \\
Employment stability (ES) & 0.810 & 0.859 & 0.597 & 0.844 & $\mathbf{0 . 8 7 9}$ & \\
Working environment (WE) & 0.611 & 0.597 & 0.427 & 0.562 & 0.638 & $\mathbf{0 . 8 9 2}$ \\
\hline
\end{tabular}

Table 4 HTMT Ratio

\begin{tabular}{lcccccc}
\hline & EP & JS & TE & EE & ES & WE \\
\hline Empowerment (EP) & & & & & & \\
Job satisfaction (JS) & 0.861 & & & & & \\
Training education (TE) & 0.678 & 0.664 & & & & \\
Employee engagement (EE) & 0.810 & 0.953 & 0.656 & & & \\
Employment stability (ES) & 0.874 & 0.912 & 0.638 & 0.911 & & \\
Working environment (WE) & 0.657 & 0.630 & 0.457 & 0.601 & 0.681 & \\
\hline
\end{tabular}

\section{Structural Model}

The structural model was performed using a bootstrapping procedure with a resample of 10,000 (Andrews \& Buchinsky, 2002; Streukens \& Leroi-Werelds, 2016) for improving the accuracy's level of the estimation. The structural model assesses all the relationships between the constructs, its corresponding beta and t-values. The results are shown in Table 5. 


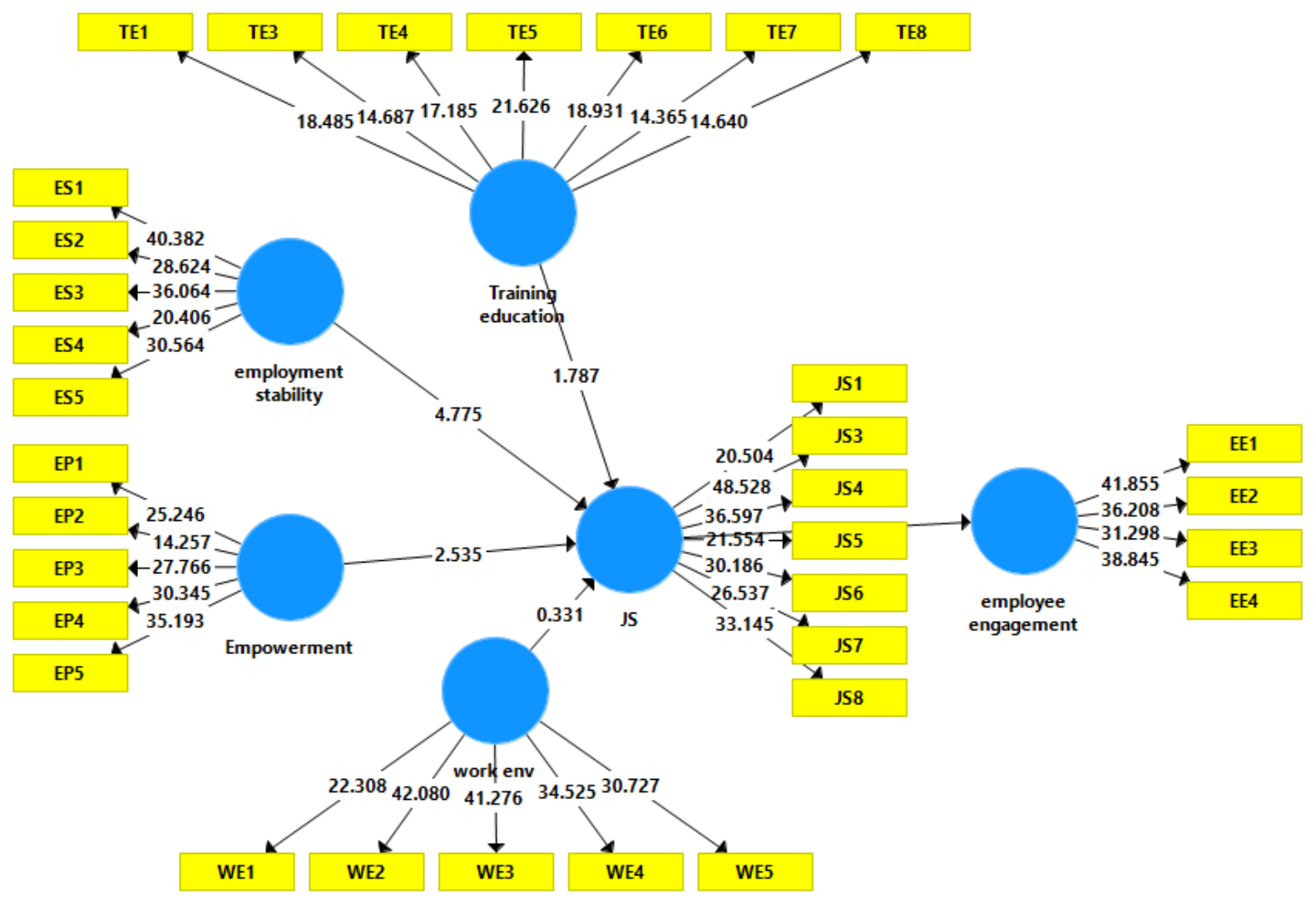

Figure 1 Structural Model

The predictors of employee empowerment $\left(\beta=0.274, t=2.535, f^{2}=0.104\right)$ and employees stability $\left(\beta=0.547, t=4.775, f^{2}=0.417\right)$, were found to have a positively significant relationship with job satisfaction. However, training and education $(\beta=$ $\left.0.117, t=1.787, f^{2}=0.037\right)$ and working environment $\left(\beta=0.030, t=0.331, f^{2}=0.002\right)$ were found to have no significant relationship with job satisfaction. In addition, job satisfaction $\left(\beta=0.895, t=34.348, f^{2}=4.038\right)$ was also found to have a positive relationship with employee engagement. These findings support $\mathrm{H}_{1}, \mathrm{H}_{3}$, and $\mathrm{H}_{5}$. The $R^{2}$ of 0.784 suggesting there is $78.4 \%$ of the variation in job satisfaction was explained by ICSR, whereas employee engagement had an $R^{2}$ of 0.802 , which indicates that job satisfaction can explain $80.2 \%$ of the variance in employee engagement.

Table 5 Structural Model Results

\begin{tabular}{ccccccccccc}
\hline & Relationship & $\begin{array}{c}\text { Std. } \\
\text { Beta }\end{array}$ & $\begin{array}{c}\text { Std. } \\
\text { error }\end{array}$ & T-value & $\mathbf{P}$ & Decision & $\mathbf{R}^{2}$ & $\mathbf{Q}^{2}$ & $\mathbf{f}^{2}$ & VIF \\
\hline $\mathrm{H}_{1}$ & EP -> JS & 0.274 & 0.108 & $2.535^{*}$ & 0.011 & Supported & 0.784 & 0.549 & 0.104 & 3.330 \\
$\mathrm{H}_{2}$ & TE -> JS & 0.117 & 0.066 & 1.787 & 0.074 & $\begin{array}{c}\text { Not } \\
\text { Supported }\end{array}$ & & 0.037 & 1.712 \\
$\mathrm{H}_{3}$ & $\mathrm{ES} \mathrm{->} \mathrm{JS}$ & 0.547 & 0.115 & $4.775^{* *}$ & 0.000 & Supported & & & 0.417 & 3.322 \\
$\mathrm{H}_{4}$ & WE -> JS & 0.030 & 0.091 & 0.331 & 0.741 & $\begin{array}{c}\text { Not } \\
\text { supported }\end{array}$ & & & 0.002 & 1.765 \\
$\mathrm{H}_{5}$ & JS-> EE & 0.895 & 0.026 & $34.348^{* *}$ & 0.000 & Supported & 0.802 & 0.607 & 4.038 & 1.000 \\
\hline Note. $^{* *} \mathrm{p}<0.01,{ }^{*} \mathrm{p}<0.05$ & & & & & & & &
\end{tabular}




\section{Mediation Analysis}

Preacher and Hayes' (2008) bootstrapping method was used to test the indirect effect of the variables. The mediating effect of JS was examined. As illustrated in Table 6 , the $\mathrm{EP} \rightarrow \mathrm{JS} \rightarrow \mathrm{EE}\left(\beta=0.246, p<0.05, \mathrm{BC}_{0.975} \mathrm{LL}=0.067\right.$ and $\left.\mathrm{UL}=0.447\right)$, $\mathrm{ES} \rightarrow \mathrm{JS} \rightarrow \mathrm{EE}\left(\beta=0.490, p<0.01, \mathrm{BC}_{0.975} \mathrm{LL}=0.271\right.$ and $\left.\mathrm{UL}=0.688\right)$, were all significant. However, $\mathrm{TE} \rightarrow \mathrm{JS} \rightarrow \mathrm{EE}\left(\beta=0.105, p>0.05, \mathrm{BC}_{0.975} \mathrm{LL}=0.003\right.$ and $\mathrm{UL}=$ $0.228)$ and $\mathrm{WE} \rightarrow \mathrm{JS} \rightarrow \mathrm{EE}\left(\beta=0.027, p>0.05, \mathrm{BC}_{0.975} \mathrm{LL}=-0.110\right.$ and $\left.\mathrm{UL}=0.203\right)$ was not significant. The confidence interval (BC) of two of the relationships as reported in Table 6 do not straddle a value of 0 in between suggesting that job satisfaction does mediate the relationships between the employee empowerment, employment stability, and employee engagement. Thus, $\mathrm{H}_{6}$ was partially supported as job satisfaction does not mediate all the relationships between ICSR practices and employee engagement.

Table 6 Results of Mediation Analysis

\begin{tabular}{|c|c|c|c|c|c|c|c|c|}
\hline & \multirow[b]{2}{*}{ Relationship } & \multirow[b]{2}{*}{$\begin{array}{l}\text { Std. } \\
\text { Beta }\end{array}$} & \multirow[b]{2}{*}{$\begin{array}{l}\text { Std. } \\
\text { error }\end{array}$} & \multirow[b]{2}{*}{$\begin{array}{c}\text { T- } \\
\text { value }\end{array}$} & \multirow[b]{2}{*}{$\mathbf{P}$} & \multicolumn{2}{|c|}{$\begin{array}{r}\text { Confident } \\
\text { (BC) }\end{array}$} & \multirow[b]{2}{*}{ Decision } \\
\hline & & & & & & $\begin{array}{c}\mathbf{L L} \\
(2.5 \%)\end{array}$ & $\begin{array}{c}\text { UL } \\
(97.5 \%)\end{array}$ & \\
\hline $\mathrm{H}_{6 \mathrm{a}}$ & EP -> JS -> EE & 0.246 & 0.097 & $2.531^{*}$ & 0.011 & 0.067 & 0.447 & Supported \\
\hline $\mathrm{H}_{6 \mathrm{~b}}$ & TE $->$ JS $->$ EE & 0.105 & 0.058 & 1.818 & 0.069 & 0.003 & 0.228 & $\begin{array}{c}\text { Not } \\
\text { Supported }\end{array}$ \\
\hline $\mathrm{H}_{6 \mathrm{c}}$ & ES $->$ JS $->$ EE & 0.490 & 0.107 & $4.573^{* *}$ & 0.000 & 0.271 & 0.688 & Supported \\
\hline $\mathrm{H}_{6 \mathrm{~d}}$ & WE $->\mathrm{JS}->\mathrm{EE}$ & 0.027 & 0.082 & 0.331 & 0.741 & -0.110 & 0.203 & $\begin{array}{c}\text { Not } \\
\text { supported }\end{array}$ \\
\hline
\end{tabular}

Note. ${ }^{* *} \mathrm{p}<0.01,{ }^{*} \mathrm{p}<0.05, \mathrm{BC}=$ Bias Corrected, UL $=$ Upper Level, $\mathrm{LL}=$ Lower Level

\section{DISCUSSION}

The findings of the study reveal that the two dimensions of ICSR, namely employee empowerment and employment stability, are positively and significantly associated with job satisfaction. Employment stability is the strongest predictor of job satisfaction, followed by employee empowerment. Therefore, this implies that the employees who perceive their institutions are maintaining good ICSR practices (employment stability and employee empowerment) will be more likely to show a higher level of satisfaction and engagement. These findings are consistent with the findings of Santoso (2014) and Esmaeelinezhad et al. (2015), which highlighted that the level of job satisfaction depends on companies that are involved in practicing good corporate citizenship.

With regard to training and education, this study showed that there is no significant relationship between training and education with job satisfaction and engagement. This finding contradicts previous studies (Obeidat et al., 2018; Paşaoğlu \& Tonus, 2014). The possible explanation is that the current study is focused on the private HEI in which 
the customer orientation is very prominent. Hence, employees need to find a balance between taking care of customers (students) for better services, at the same time attending training to improve their skills in a job. This has somehow caused the employees to become dissatisfied. In addition, the organization also has its policy and yearly key performance indexes (KPIs) to achieve, as well as the need to comply with certain hours of training and education. The pressure of having to juggle the two may be the cause of dissatisfaction. Not all training is useful and beneficial to the employees. In the long run, unnecessary training will cause a burden to the employees, which explained the current findings where there is no significant relationship between training \& education and job satisfaction.

Contradicting to previous studies by Low (2015), Mory et al. (2015), Cavazotte and Chang (2016), Thang and Fassin (2017) who found working environment has a significant and positive association with job satisfaction. The findings coincided with the Herzberg's Motivation Hygiene Theory (1966) which claimed that low satisfactory working environment will lead to job dissatisfaction among employees. The possible reason might be due to the organization under study, which is a private learning institution having various ISO policies, whereby the process of work might be influenced by the bureaucratic culture and the pressure to perform in a tight deadline, leading to a less satisfactory working climate.

The result of the statistical analysis also shows that employee empowerment has a positive and significant relationship with job satisfaction and engagement. This implies that employees are keen to reciprocate with a higher job satisfaction when they can understand that the institutions are providing efforts to make a balance between work environment and employees' wellbeing, in particular, giving an opportunity for the decision making process to happen among employees. Mory et al. (2015) mentioned that empowerment through the decision making process would help in enhancing job satisfaction. As a result, it strengthens the self-efficacy and confidence (Ugboro \& Obeng, 2000).

In addition, the current results contradict studies by Obeidat et al. (2018) and Esmaeelinezhad et al. (2015), where employment stability has a positive and significant relationship with job satisfaction. One plausible cause is that job stability gives comfort, support, and security for employees (Mory et al., 2015). In addition, employment stability provides empirical support for the social exchange theory, suggesting that job stability is an individual's desire point that can motivate employees to repay the organization.

This study provides statistical evidence for the mediating role of job satisfaction in the relationship between two ICSR practices (employee empowerment, employment stability) and employee engagement. This finding was congruent with numerous past 
studies (Devi \& Nagni, 2013; Hadjimanolis \& Boustras, 2013), which indicate that job satisfaction can mediate the relationship between ICSR practices and engagement in a positive way. The idea behind is once employees perceived ICSR practices more positively, they will feel happy with the actions done by the organization.

\section{CONCLUSION}

In conclusion, this study has identified the dimensions of ICSR practices that can cause employees to have engagement with the organizations, namely employee empowerment and employment stability. This study also found that employment stability is a prominent factor that contributes to job satisfaction. In addition, the study also found that job satisfaction mediates the relationship between two ICSR practices, namely employee empowerment and employment stability, with employee engagement, in particular, HEI understudied.

\section{Theoretical Contribution}

This study provides an empirical insight on Social Exchange Theory (Homans, 1961) as employees and employers are keen to make an interactive relationship in the form of exchange and mutual benefits. Findings indicated that job satisfaction among employees is positively related to employee engagement in the organization. From the theoretical perspective, the exchange or reciprocal connection will create an eagerness among employees to ensure their benefits; in return, this will induce them to be loyal to the organization.

This study also reported there is a significant outcome of the mediating role. It is shown that job satisfaction mediated the relationship between ICSR practices and employee engagement. The interaction between ICSR practices with job satisfaction and between job satisfaction and employee engagement is being improved by ICSR practices within organizations. Previous studies verified that the level of engagement among employees depends on the level of ICSR as being exercised within an organization. In this study, the employees may have higher engagement in university because the HEI ensuring employment stability and empower their workers.

\section{Practical Implications}

The study has several managerial implications. First of all, if the HEIs want to establish a relationship with employees, they need to ensure the useful predictors of job satisfaction. The study suggested that organizations need to have frequent personal interactions with employees, whereby employees' voices can be heard by the top management as it will enhance engagement and attachment. The top authorities can use this study as a guide to examine the most expected dimensions of ICSR and incorporate 
it strategically in the organization system to inspire their employees for engagement. Hence, the management has to take into consideration the prominent factors of ICSR, such as job security and empowerment, to provide an exceptional and memorable working life. By implementing these dimensions, both parties will notice the exchanging advantages and subsequently will enhance the relationship.

\section{Limitations and Recommendations for Future Study}

The current study only limits to the employees in one private HEI. Hence, in the future, a larger number of respondents from similar or different universities can be included to enhance the accuracy of the results and able to make generalizations. In addition, the future study can make a comparison between the ICSR initiatives practiced by public and private universities as it will provide meaningful information about the practices of ICSR.

Another limitation exists regarding the issue of social desirability bias, wherein respondents may answer according to what they think is socially desirable, as employees are scared that the data might be shown to top management and consequently have some negative effects on their jobs. Hence, there are tendencies for employees to be biased in giving their responses. However, the researchers attempted to minimize this limitation by creating an anonymous instrument and assuring respondents of the data's confidentiality.

Moreover, future studies can include other mediating variables instead of job satisfaction, such as employee identification, employer branding, organization-public relationships (OPRs) to make the current model more robust. In terms of methodology, the current study only uses a quantitative survey method. Future research can employ qualitative approaches, such as interviews or mixed methods, to be complementary to the deficiency of the quantitative approach. The integration of quantitative and qualitative methods will provide in-depth information on the arena of CSR and yield better results.

\section{ACKNOWLEDGEMENT}

The early version of the work has been presented and included in the conference proceeding of the International Conference on Communication, Language, Education, and Social Sciences (CLESS) 2019; Multimedia University (MMU).

\section{REFERENCES}

Andrews, D. W., \& Buchinsky, M. (2002). On the number of bootstrap repetitions for BCa confidence intervals. Econometric Theory, 18(4), 962-984.

https://doi.org/10.1017/s0266466602184088 
Albdour, A. A., Ali, A., Nasruddin, E., \& Soh, K. L. (2010). The relationship between internal corporate social responsibility and organizational commitment within the banking sector in Jordan. International Scholarly and Scientific Research \& Innovation, 4(7), 1842-1861. https://doi.org/10.5281/zenodo.1054799

Aturupane, H., \& Richard, R. (2019). How can Malaysia realize the potential of its human capital?. World Bank.

https://blogs.worldbank.org/eastasiapacific/how-can-malaysia-realize-potentialits-human-capital

Awang, Z., Afthanorhan, A., Asri, M. A. M. (2015)._Parametric and non parametric approach in structural equation modeling (SEM): The application of bootstrapping. Modern Applied Science, 9(9), 58-67.

https://doi.org/10.5539/mas.v9n9p58

Babbie, E. R. (2015). The practice of social research (14 ${ }^{\text {th }}$ ed.). Cengage Learning

Bagozzi, R. P., Yi, Y., \& Phillips, L. W. (1991). Assessing construct validity in organizational research. Administrative Science Quarterly, 36(3), 421-458. https://doi.org/10.2307/2393203

Barakat, S. R., Isabella, G., Boaventura, J. M., \& Mazzon, J. A. (2016). The influence of corporate social responsibility on employee satisfaction. Management Decision, 54(9), 2325-2339. https://doi.org/10.1108/MD-05-2016-0308

Bayraktar, O., \& Şencan, H. (2017). Employees' approaches to human resources from the asset-resource concepts perspective. International Journal of Business and Social Science, 8(9), 116-127.

Blau, P. (1964). Exchange and power in social life. Wiley.

Bakotić, D. (2016). Relationship between job satisfaction and organizational performance. Economic Research - EkonomskaIstraživanja, 29(1), 118-130. https://doi.org/10.1080/1331677X.2016.1163946

Cavazotte, F., \& Chang, N. C. (2016). Internal corporate social responsibility and performance: A study of publicly traded companies. BAR - Brazilian Administration Review, 13(4), 64-94. https://doi.org/10.1590/1807$\underline{7692 \text { bar2016160083 }}$

Chan, T. J., \& Mohd Hasan, N. A. (2018). Corporate social responsibility practices from the employees' perspective: A case of Malaysian higher education institution. International Journal of Academic Research in Business and Social Sciences, 8(4), 132-153. https://doi.org/10.6007/IJARBSS/v8-i4/4003

Chan, T. J., \& Mohd Hasan, N. A. (2019). Internal corporate social responsibility practices and employees' job satisfaction in a Malaysian banking company. Jurnal Pengurusan, 55, 97-109. https://doi.org/10.17576/pengurusan-2019-55-08 
Crede, M., Chernyshenko, O. S., Stark, S., Dalal, R, S., \& Bashshur, M. R. (2007). Job satisfaction as mediator: An assessment of job satisfaction's position within the nomological network. Journal of Occupational and Organizational Psychology, 80(3), 515-538. https://doi.org/10.1348/096317906X136180

de Leeuw, E. D. (2008). Choosing the method of data collection. In de Leeuw, E. D., Hox J. J., \& Dillman D. A. (Eds.), International handbook of survey methodology (pp. 113-135). Lawrence Erlbaum Associates.

Devi, V. R., \& Nagini, A. (2013). Work-life balance and burnout as predictors of job satisfaction in private banking sector. Skyline Business Journal, 9(1), 50-53.

Esmaeelinezhad, O., Singaravelloo, K., \& Boerhannoeddin, A. (2015). Linkage between perceived corporate social responsibility and employee engagement: Mediation effect of organizational identification. International Journal of Human Resource Studies, 5(3), 174-191. https://doi.org/10.5296/ijhrs.v5i3.8376

Etikan, I., Musa, S. A., \& Alkassim, R. S. (2016). Comparison of convenience sampling and purposive sampling. American Journal of Theoretical and Applied Statistics, 5(1), 1-4. https://doi.org/10.11648/j.ajtas.20160501.11

Farid, T., Iqbal, S., Ma, J. Castro-González, S., Khattak, A., \& Khan, M. K. (2019). Employees' perceptions of CSR, work engagement, and organizational citizenship behavior: The mediating effects of organizational justice.

International Journal of Environment Research and Public Health, 16(10), 1731. https://doi.org/10.3390/ijerph16101731

Fornell, C., \& Larcker, D. F. (1981). Evaluating structural equation models with unobservable variables and measurement error. Journal of Marketing Research, 18(1), 39-50. https://doi.org/10.2307/3151312

Fu, H., Ye, B., \& Law, R. (2014). You do well and I do well? The behavioural consequences of corporate social responsibility. International Journal of Hospitality Management, 40, 62-70. https://doi.org/10.1016/j.ijhm.2014.03.004

Gao, J. H. (2019). Examining corporate social responsibility and employee engagement in Macao. International Journal of Business and Management, 12(3), 1380-1402. https://doi.org/10.4018/978-1-5225-6192-7.ch072

Gharleghi, B., Jahanshahi, A. A., \& Nawaser, K. (2018). The outcomes of corporate social responsibility to employees: Empirical evidence from a developing country. Sustainability, 10(3), 698. https://doi.org/10.3390/su10030698

Ghasemy, M., Hussin, S., Megat Daud, M. A. K., Md. Nor, M., Ghavifekr, S., \& Kenayathulla, H. B. (2018). Issues in Malaysian higher education: A quantitative representation of the top five priorities, values, challenges, and solutions from the viewpoints of academic leaders. SAGE Open, 8(1), 1-15.

https://doi.org/10.1177/2158244018755839 
Gold, A. H., Malhotra, A., \& Segars, A. H. (2001). Knowledge management: An organizational capabilities perspective. Journal of Management, 18(1), 185-214. https://doi.org/10.1080/07421222.2001.11045669

Hadjimanolis, A., \& Boustras, G. (2013). Health and safety policies and work attitudes in Crypriot companies. Safety Science, 52(8), 50-56. https://doi.org/10.1016/j.ssci.2012.03.012

Hair, J. F., Hult, G., Tomas, M., Ringle, C. M., \& Sarstedt, M. (2017). A primer on Partial Least Squares Structural Equation Modeling (PLS-SEM): SAGE Publications, Incorporated.

Hair, J. F., Ringle, C. M., \& Sarstedt, M. (2011). PLS-SEM: Indeed a silver bullet. Journal of Marketing Theory and Practice, 19(2), 139-152. https://doi.org/2010.2753/MTP1069-6679190202

Hair, J., Risher, J., Sarstedt, M., \& Ringle, C. (2019). When to use and how to report the results of PLS-SEM. European Business Review, 31(1), 2-24. https://doi.org/2010.1108/EBR-11-2018-0203

Henseler, J., Ringle, C. M., \& Sinkovics, R. R. (2009). The use of partial least squares path modeling in international marketing. Advances in International Marketing, 20, 277-319. https://doi.org/10.1108/S1474-7979(2009)0000020014

Henseler, J., Ringle, C. M., \& Sarstedt, M. (2015). A new criterion for assessing discriminant validity in variance-based structural equation modeling. Journal of the Academy of Marketing Science, 43(1), 115-135. https://doi.org/10.1007/20s11747-014-0403-8

Herzberg, F. (1966). Work and the nature of man. World Publishers.

Homans. G. C. (1961). Social behavior. Harcourt Brace.

Hansen, S. D., Dunford, B. B., Boss, A. D., Boss, R. W., \& Angermeier, I. (2011). Corporate social responsibility and the benefits of employee trust: A crossdisciplinary perspective. Journal of Business Ethics, 102(1), 29-45. https://doi.org/2010.1007/s10551-011-0903-0

Idris, A., See, D., \& Coughlan, P. (2018). Employee empowerment and job satisfaction in Urban Malaysia. Journal of Organizational Change Management, 31(3), 697-711. https://doi.org/10.1108/JOCM-04-2017-0155

Khan, M. A., Md. Yusoff, R., Hussain, A., \& Ismail, F. (2019)._The mediating effect of job satisfaction on the relationship of HR practices and employee job performance: Empirical evidence from higher education sector. International Journal of Organizational Leadership, 8, 78-94. https://doi.org/10.33844/ijol.2019.60392

Kline, R. B. (2011). Principles and practice of structural equation modelling. Guilford Press. 
Lee, C. H., \& Bruvold, N, T. (2003). Creating value for employees: Investment in training and education. International Journal of Human Resource Management, 14(6), 981-1000. https://doi.org/10.1080/0958519032000106173

Lee, M., \& Kim, W. (2013). The effect of perceived corporate social responsibility on hotel employee's attitude and behavior toward the organization. International Journal of Tourism Sciences, 13(3), 51-74. https://doi.org/10.1080/2015980634.2013.11434680

Lim, B. K., Ramakrishnan, S., \& Hishan, S. S. (2018) Corporate social responsibility practice of Malaysian public listed government-linked companies: A dimensional analysis. Management Science Letters, 8(5), 417-426.

https://doi.org/10.5267/20j.msl.2018.4.005

Peng, L. M. (2015). A study of internal corporate social responsibility practices in small medium enterprises located in the state of Selangor. Journal of Research on Humanities and Social Sciences, 5(6), 14-35.

Peng, L. M. (2020). The divergent influence of social responsibility on employee engagement through the lens of marital status: Evidence from higher education institutions. Review of Business Management, 22(2), 205-231. https://doi.org/2010.7819/rbgn.v22i2.4046

Low, M. P., \& Ong, S. F. (2015). The manifestation of internal corporate social responsibility on employees' behavior in small medium sized enterprises. Journal of Social Sciences Studies, 2(2), 259-277. https://doi.org/10.5296/jsss.v2i2.7659

Low, M. P., Ong, S. F., \& Tan, P. M. (2017). Would internal corporate social responsibility make a difference in professional service industry employees' turnover intention? A two stage approach using PLS-SEM. Global Business and Management Research: An International Journal, 9(1), 24-41

Macdonald, S., \& Maclntyre, P. (1997). The generic job satisfaction scale: Scale development and its correlates. Employee Assistance Quarterly, 13(2), 1-16. https://doi.org/10.1300/J022v13n02 01

Manimegalai, S., \& Baral, R. (2018). Examining the mediating role of organizational trust in the relationship between CSR practices and job outcomes. Social Responsibility Journal, 14(3), 433-447. https://doi.org/10.1108/SRJ-01-2017$\underline{0007}$

Mory, L., Wirtz, B. W., \& Göttel, V. (2016). Factors of internal corporate social responsibility and the effect on organizational commitment. The International Journal of Human Resource Management, 27(13), 1393-1425. https://doi.org/2010.1080/09585192.2015.1072103 
Hernández-Murillo, R., \& Martinek, C. J. (2009). Corporate social responsibility can be profitable. The Regional Economist, (Apr), 4-5.

https://www.stlouisfed.org/ /20media/files/pdfs/publications/pub assets/pdf/re/2 009/b/socialresponsibility.pdf

Obrad, C., \& Gherheş, V. (2018). A human resources perspective on responsible corporate behavior. Case study: The multinational companies in western Romania. Sustainability, 10(3), 726. https://doi.org/10.3390/su10030726

Obeidat, B. Y., Altheeb, S., \& Masa'deh, R. (2018). The impact of internal corporate social responsibility on job satisfaction in Jordanian pharmaceutical companies. Modern Applied Science, 12(11), 105-120.

https://doi.org/10.5539/20mas.v12n11p105

Paşaoğlu, D., \& Tonus, H. Z. (2014). Strategic importance of human resource practices on job satisfaction in private hospitals. Procedia-Social and Behavioral Sciences, 150, 394-403. https://doi.org/10.1016/j.sbspro.2014.09.035

Podsakoff, P. M., MacKenzie, S. B., Lee, J. Y., \& Podsakoff, N. P. (2003). Common method biases in behavioral research: A critical review of the literature and recommended remedies. Journal of Applied Psychology, 88(5), 879-903. https://doi.org/10.1037/0021-9010.88.5.879

Preacher, K. J., \& Hayes, A. F. (2008). Asymptotic and resampling strategies for assessing and comparing indirect effect in multiple mediator models. Behaviour Research Methods, 40(3), 879-891. https://doi.org/10.3758/brm.40.3.879

Ramasamy, V., \& Abdullah, N. H. (2017). Faculty's turnover in private higher learning Institutions: A phenomenal inquiry. BEH Business and Economics Horizon, 13(2), 169-181. https://doi.org/10.15208/beh.2017.13

Ramayah, T., Cheah, J., Chuah, F., Ting, H., \& Memon, M. A. (2018). Partial least squares structural equation modeling (PLS-SEM) using smartPLS 3.0. In $A n$ Updated Guide and Practical Guide to Statistical Analysis ( $2^{\text {nd }}$ ed.). Pearson.

Ranjan, S., \& Yadav, R. S. (2018). Uncovering the role of internal CSR on organizational attractiveness and turnover intention: The effect of procedural justice and extraversion. Asian Social Science, 14(12), 76-85. https://doi.org/2010.5539/ass.v14n12p76

Sani, R., \& Mustafa, Z. (2019). What lies ahead in 2019 for higher education?. New Straits Times. https://www.nst.com.my/education/2019/01/446228/what-liesahead-2019-higher-education.

Santoso, I. L. (2014). The impact of internal CSR towards employee engagement and affective commitment in XYZ hotel Surabaya. Business Management, 2(2), 7988 . 
Sekaran, U., \& Bougie, R. (2016). Research methods for business: A skill building approach $\left(7^{\text {th }}\right.$ ed.). John Willey and Sons, Inc.

Singh, P. J., Sethuraman, K., \& Lam, J. Y. (2017). Impact of corporate social responsibility dimensions on firm value: Some evidence from Hong Kong and China. Sustainability, 9(9), 1532. https://doi.org/10.3390/su9091532

Slack, R. E., Corlett, S., \& Morris, R. (2015). Exploring employee engagement with (corporate) social responsibility: A social exchange perspective on organizational participation. Journal of Business Ethics, 127, 537-548. https://doi.org/10.1007/20s10551-014-2057-3

Streukens, S., \& Leroi-Werelds, S. (2016). Bootstrapping and PLS-SEM: A step-bystep guide to get more out of your bootstrap results. European Management Journal, 34(6), 618-632. https://doi.org/10.1016/j.emj.2016.06.003

Tehseen, S., Ramayah, T., \& Sajilan, S. (2017). Testing and controlling for common method variance: A review of available methods. Journal of Management Sciences, 4(2), 146-175. https://doi.org/10.20547/jms.2014.1704202

Tepayakul, R., \& Rinthaisong, I. (2018). Job satisfaction and employee engagement among human resources staff of Thai private higher education institutions. The Journal of Behavioral Science, 13(2), 68-81.

Thang, N. N., \& Fassin, Y. (2017). The impact of internal corporate social responsibility on organizational commitment: Evidence from Vietnamese service firms. Journal of Asia-Pacific Business, 18(2), 100-116. https://doi.org/10.1080/2010599231.2017.1309617

The World Bank. (2019). Malaysia's 'critical occupations list' is an innovative tool for preparing workers for the jobs of the future. World Bank. https://www.worldbank.org/en/news/press-release/2019/09/12/malaysias-criticaloccupations-list-is-an-innovative-tool-for-preparing-workers-for-the-jobs-of-thefuture-world-bank

Tongco, M. D. (2007). Purposive sampling as a tool for informant selection. Ethnobotany Research and Applications, 5(1), 147-158. https://doi.org/10.17348/20era.5.0.147-158

Ugboro, I. O., \& Obeng, K. (2000). Top management leadership, employee empowerment, job satisfaction, and customer satisfaction in TQM organizations: An empirical study. Journal of Quality Management, 5(2), 247-272. https://doi.org/10.1016/S1084-8568(01)00023-2

Zulfiqar, S., Sadaf, R., Popp, J., Vveinhardt, J., \& Máté, D. (2019). An examination of corporate social responsibility and employee behavior: The case of Pakistan. Sustainability, 11(13), 3515. https://doi.org/10.3390/su11133515 
Mr. Md. Monir Hossen is a postgraduate student at Faculty of Business, Social Sciences and Hospitality Management, SEGi University, Malaysia. He completed his Master's degree in Corporate Communication, and his research interests include Corporate Social Responsibility, Marketing, and Communication Management.

Mr. Tak-Jie Chan (Corresponding author) is a lecturer at the Faculty of Business, Social Sciences and Hospitality Management, SEGi University as well as a PhD candidate at Putra Business School, Malaysia. His research areas include Corporate Social Responsibility, Marketing \& Corporate Communication, Organizational Studies, and topics related to Strategic Communication Management.

Dr. Nurul Ain Mohd Hasan is an associate professor at the Department of Communication, Faculty of Modern Languages and Communication, Universiti Putra Malaysia, Malaysia. She also a committee member under the education chapter of the Institute of Public Relations Malaysia. She received her PhD in Communication from Massey University in New Zealand. Her research field is Corporate Social Responsibility in Communication and Public Relations. 